\title{
Peran jurnalisme warga dalam pemberdayaan masyarakat desa
}

\author{
Edi Santoso', Imam Prawoto Jati², Dian Bestari ${ }^{3}$ \\ ${ }^{1,2,3}$ Universitas Jenderal Soedirman, Purwokerto, Indonesia
}

\begin{abstract}
ABSTRAK
Kemudahan akses Internet bagi masyarakat belum diikuti dengan kemampuan untuk memanfaatkannya secara konstruktif. Program jurnalisme warga bisa menjadi salah satu sarana untuk memanfaatkan Internet, khususnya melalui media sosial, untuk program-program pemberdayaan sosial di pedesaan. Keberadaan Internet telah mendorong gairah baru praktik jurnalisme warga. Penelitian ini menelaah praktik jurnalisme warga di Kabupaten Brebes yang memanfaatkan Blog dan Facebook untuk kegiatan pemberdayaan masyarakat desa. Tujuan penelitian ini adalah menyajikan model pemanfaatan media sosial sebagai praktik jurnalisme warga untuk pemberdayaan masyarakat pedesaan. Metode penelitian menggunakan pendekatan kualitatif, dengan teknik pengambilan data berupa analisis isi media, wawancara mendalam, dan diskusi kelompok terarah. Hasil penelitian menunjukkan bahwa agenda jurnalisme warga paralel dengan upaya-upaya pemberdayaan masyarakat, khususnya dalam bidang pendidikan, kesehatan, dan lingkungan. Para jurnalis warga menggunakan istilah "Story of Change" sebagai indikator kinerja mereka dalam memberdayakan masyarakat. Perubahan ini didorong oleh opini publik yang mereka ciptakan, melalui strategi publikasi yang mencakup tiga agenda, yakni to inform, to promote, dan to advocate. Perubahan diciptakan dengan melibatkan pemerintah, swasta, dan masyarakat secara umum, baik melalui kebijakan resmi pihak yang berwenang ataupun dukungan dana dari masyarakat (crowd funding). Simpulan penelitian ini keberdayaan masyarakat ditunjukkan secara individual maupun sosial. Secara individual, para jurnalis warga merasa lebih percaya diri dan bertumbuh secara pengetahuan.
\end{abstract}

Kata-kata Kunci: Jurnalisme warga; media; pemberdayaan masyarakat; sosial; media sosial

\section{The role of citizens journalism in empowerment of rural communities}

\section{ABSTRACT}

Ease of Internet access for the public has not been followed by the ability to use it constructively. Citizen journalism programs can be a means of utilizing the Internet, primarily through social media, for social empowerment programs in rural areas. The existence of the Internet has encouraged a new passion for the practice of citizen journalism. This study examines the practice of citizen journalism in the Brebes Regency that utilizes Blogs and Facebook for village community empowerment activities. The purpose of this study is to present a model of using social media as a practice of citizen journalism for empowering rural communities. The research method uses a qualitative approach, with data collection techniques in the form of media content analysis, in-depth interviews, and focus group discussions. The results show that the agenda of citizen journalism was paralleled with efforts to empower the community, especially in the fields of education, health, and the environment. Citizen journalists use the term "Story of Change" as an indicator of their performance in empowering the community. This change was driven by the public opinion they created, through a publication strategy that included three agendas, namely to inform, to promote, and to advocate. Change is created by involving the government, the private sector, and the community in general, both through official policies of the authorities or crowdfunding. The conclusion of this research is the community empowerment shown individually and socially. Individually, citizen journalists feel more confident and grow in knowledge.

Keywords: Journalism; citizen; enpowerment; social; media; social media

Korespondensi: Dr. Edi Santoso, M.Si. Universitas Jenderal Soedirman. Jl. Profesor DR. HR Boenyamin No.708, Grendeng, Kec. Purwokerto Utara, Kabupaten Banyumas, Jawa Tengah 53122. Email: edisant@, gmail.com 


\section{PENDAHULUAN}

Sebagai sebuah praktik, jurnalisme warga (citizen journalism) memang bukan hal baru di Indonesia. Olivia Lewi Pramesti menyebutkan bahwa praktik jurnalisme warga di Indonesia dipelopori oleh Radio Sonora Jakarta saat kerusuhan Mei 1998. Para pendengar melaporkan apa yang dilihat dan dialami ke radio tersebut. Sementara itu, penelitian Moch. Nunung Kurniawan menunjukkan bahwa Radio Elshinta sejak tahun 2000 telah mempelopori jurnalisme warga dengan jumlah reporter hingga 100.000 orang. Keberhasilan Elshinta ini mengalahkan situs jurnalisme warga pertama di Korea Selatan, ohmynews yang memiliki 40.000 reporter (Ningtyas, 2014). Perkembangan teknologi semakin memudahkan praktik jurnalisme warga di Indonesia, misalnya Net TV yang mempunyai acara Citizen Journalism (Net CJ) dengan mengoptimalkan tren konvergensi media (Vebrynda, Maryani, \& Abdullah, 2017).

Kehadiran Internet semakin menguatkan eksistensi jurnalisme warga, seiring dengan meningkatnya akses Internet oleh masyarakat. Berdasarkan survei Asosiasi Penyedia Jasa Internet Indonesia (APJII) tahun 2016, pengguna Internet di Indonesia sudah mencapai angka 132,7 juta orang atau 51,8 persen dari total populasi Indonesia. Dari jumlah itu, hampir semuanya $(97,4 \%)$ menggunakan media sosial (Asosiasi Penyelenggara Jasa Internet Indonesia, 2017). Penetrasi media sosial telah mengalahkan media lainnya, kecuali televisi. Melalui media sosial inilah, masyarakat berperan sebagai jurnalis warga (citizen journalist). Mereka berbagi informasi, layaknya jurnalis pada umumnya, melalui berbagai platform media sosial, seperti Blog, Facebook, Twitter, atau Instagram.

Dalam studi yang dilakukan Wedhaswary (2009), ditemukan fakta bahwa keberadaan Internet telah mendorong gairah baru praktik jurnalisme warga. Kemudahan akses melalui teknologi Internet telah mendorong peran serta dan keterlibatan warga dalam produksi dan distribusi informasi. Ada 'sense of journalism' yang meningkat dalam masyarakat, yang ditunjukkan fenomena semakin banyaknya informasi penting yang datang dari masyarakat bukan wartawan (non-profesional). Masyarakat tak lagi menjadi pihak yang pasif, hanya menerima dan mengkonsumsi informasi, tetapi kini mereka banyak yang juga menjadi produsen berita. Ada perubahan yang mendasar dalam praktik produksi dan konsumsi berita, yang semakin menempatkan masyarakat dalam posisi penting.

Media sosial, dalam banyak hal memang sudah dimanfaatkan untuk kegiatan positif. Seperti yang ditulis Hartoyo dan Supriadi, media sosial dimanfaatkan untuk aktivitas sosial, misalnya dalam kampanye pemberian ASI eksklusif oleh Asosiasi Ibu Menyusui Indonesia (AIMI) (Hartoyo \& Supriadi, 2015). Media sosial juga banyak dimanfaatkan untuk kegiatan-kegiatan produksi, misalnya oleh UMKM untuk pemasaran produk. Seperti pendampingan yang dilakukan Universitas Muria Kudus kepada pengrajin sangkar burung, dengan memanfaatkan media sosial sebagai sarana utama dalam pemasarannya (Solekhan \& Winarso, 2016). Secara personal, media sosial juga menyediakan peluang untuk bertumbuh. Seperti penelitian Gündüz (2017), platform media sosial semakin penting dalam kehidupan karena mereka adalah tempat di mana kita "memamerkan" pengalaman hidup kita. Mereka juga mencerminkan berbagai dimensi mengenai posisi kami di kehidupan sosial virtual dan fisik. Kedua faktor ini membuat orang memainkan karakter tertentu dalam arena sosial. Jejaring sosial semakin penting di dunia saat ini dan semakin dalam berdampak pada masyarakat seperti pada media tradisional. Media sosial memungkinkan ekspresi identitas, eksplorasi, dan eksperimentasi. Sayangnya, secara umum, media sosial sering dikaitkan dengan berbagai persoalan masyarakat, misalnya ancaman disintegrasi bangsa yang belakangan jadi perbincangan banyak kalangan. Media sosial kini telah menjadi ladang subur bagi muatan berupa hasutan, fitnah, berita bohong, dan ujaran kebencian. Di media sosial, orang menjadi gampang marah dan bersumbu pendek (Kompas, 2017). Bahkan untuk kalangan muda yang terpelajar saja masih jadi korban hoax melalui media sosial, apalagi untuk level masyarakat di bawahnya (Mujahiddin \& Harahap, 2017). Dalam perspektif psikologi sosial, fenomena yang hadir bersama media sosial seperti online shopping, selfie, user-personalization, dan shared-culture, menyimpan masalah-masalah besar (Mulawarman \& Nurfitri, 2017). 
Sebagai sebuah produk teknologi informasi dan komunikasi, kehadiran media sosial memang tidak terelakkan. Kita mungkin tak perlu panik dan melarang penggunaan media sosial, tetapi perlu upaya mengantisipasi dampaknya. Selain dampak negatif, tentu saja ada dampak positif penggunaan media sosial ini. Sisi positif dan konstruktif inilah yang harus terus didorong. Dalam perspektif Social Construction of Technology (SCOT), teknologi mestinya bukan yang mengarahkan hidup manusia (technological determenism), tetapi sebaliknya, manusialah yang harus membentuk penggunaan teknologi. Dalam perspektif ini, frame teknologi oleh masyarakat yang akan mengarahkan pemaknaan atas teknologi (Yousefikhah, 2017). Jika hari ini orang semakin merasa tak bisa melepaskan diri dari media sosial, sebetulnya semua berangkat dari orang yang bersangkutan memaknai perangkat atau aplikasi tersebut. Anggapan bahwa 'media sosial semakin tak terelakkan' sendiri, bisa dianggap sebagai konstruksi sosial. Itulah anggapan-anggapan yang berkembang di tengah-tengah masyarakat, yang pada akhirnya mempengaruhi sikap individu (Stark, Fins, \& Stark, 2012).

Dalam logika SCOT itu pula, berbagai upaya perlu dilakukan untuk menemukan model pemanfaatan media sosial dalam berbagai bidang. Salah satu bidang yang perlu dikaji adalah perdesaan, dimana pemerintah saat ini menjadikannya sebagai fokus utama pembangunan. Setidaknya, ini nampak dari kebijakan pendanaan pembangunan desa. Dengan payung hukum Undang-Undang No. 6 Tahun 2014 tentang Desa, pemerintah, untuk pertama kalinya, memberikan dana desa, langsung dari APBN untuk dikelola masyarakat desa. Tahun 2016, telah direalisasikan pencairan dana desa sebesar Rp 46,9 triliun. Setiap desa mengelola uang secara mandiri sebesar Rp 500-800 juta. Pada tahun 2017, total dana desa dari APBN meningkat, menjadi Rp 60 triliun, sehingga masyarakat desa sudah bisa mengelola dana desa hampir Rp 1 miliar per desa.

Tapi masalah desa tak selesai dengan dana besar, bahkan yang tak terelakkan kemudian justru jebakan korupsi. Komisi Pemberantasan Korupsi (KPK) menyebut, laporan pelaporan penyelewengan dana desa sangat tinggi. Sampai akhir 2016 saja, KPK menerima 300 laporan masyarakat soal dugaan penyelewengan dana desa (Kompas, 2017). Sementara itu, alokasi danajuga sebagian besar masih pada proyek fisik, belum menyentuh aspek sosial yang bertumpu pada sisi keberdayaan masyarakat. Walhasil, pembangunan desa belum beranjak jauh. Masalah sosial ekonomi masih menggelayuti wilayah perdesaan pada umumnya. Masalah di desa, tak bisa semata diselesaikan dengan pendekatan anggaran. Kunci pembangunan desa, justru paling utama ada di tangan masyarakatnya. Masyarakat desa yang berdaya, yang akan menjadi kekuatan pembangunan di perdesaan. Penggunaan medsos yang juga meluas ke wilayah perdesaan harus sejalan dengan manfaatnya. Sumber daya perdesaan, baik dan sosial, yang secara umum belum dikembangkan secara maksimal bisa menjadi momentum bagi ledakan media sosial. Sejauh ini, pemerintah lebih banyak memfasilitasi aspek infrastruktur. Ini tidak terlepas dari amanah UU No 6 Tahun 2014 tentang desa (khususnya pasal 86), bahwa desa berhak mendapatkan akses informasi melalui sistem informasi yang dikembangkan oleh Pemerintah Daerah Kabupaten atau Kota. Dalam pasal tersebut ditegaskan, desa berhak mendapatkan akses informasi melalui sistem informasi Desa yang dikembangkan oleh Pemerintah Daerah Kabupaten atau Kota. Pemerintah dan Pemerintah Daerah wajib mengembangkan sistem informasi Desa dan pembangunan Kawasan Perdesaan, yang meliputi fasilitas perangkat keras dan perangkat lunak, jaringan, serta sumber daya manusia. Dalam praktiknya, dukungan ini lebih berfokus pada penyedian domain web, sebagai ruang penyediaan informasi desa. Aspek pemberdayaan sumber daya manusia belum banyak tersentuh.

Dengan adanya model pemanfaatan jurnalisme warga berbasis media sosial untuk pembangunan desa, program pemerintah di bidang teknologi informasi dan perdesaan akan terdukung dan berjalan paralel. Pemerintah bisa mengadopsinya sebagai kebijakan di bidang komunikasi dan informasi. Ini bisa menjadi gerakan kolaborasi, antara pemerintah dan gerakan masyarakat. Misalnya pemerintah menyediakan web melalui Sistem Informasi Desa, masyarakat menjadi relawan pengisi web tersebut melalui berita-berita produk jurnalisme warga.

Salah satu sisi strategis jurnalisme warga adalah pada kemampuannya untuk 
mendorong partisipasi masyarakat. Beberapa riset mengkonfirmasi hal ini, antara lain yang ditulis Mody, bahwa proyek jurnalisme warga telah mendorong partisipasi sipil dalam isu kemanusiaan di Darfur (Mody, 2011). Begitu juga dengan penelitian $\mathrm{Nah}$ et. al. yang menegaskan bahwa praktik jurnalisme warga memiliki efek langsung dalam mendorong partisipasi masyarakat dan meningkatkan jiwa kerelawanan dalam berbagai organisasi sosial (Nah, Namkoong, Record, \& Van Stee, 2017). Sementara itu Pain menyajikan temuan bagaimana jurnalisme warga di dua wilayah yang sangat miskin sumber daya di India bisa memobilisasi komunitas dan memicu gerakan menuntut perubahan. Sebagai kajian adalah kiprah relawan Video dan CGNET Swara, dua organisasi jurnalisme warga yang bekerja di India Tengah, di daerah-daerah yang indeks manusia dan pembangunan termasuk yang terendah di negara ini. Para aktivis organisasi tersebut melatih warga untuk memproduksi berita, jenis bingkai yang digunakan, untuk memobilisasi pemirsa dan mendorong mereka untuk mengartikulasikan kemarahan terhadap kekejaman hak asasi manusia yang terjadi di daerahnya. Temuan menunjukkan bahwa jurnalisme warga berhasil, karena bingkai budaya yang digunakan beresonansi dengan khalayak dan produsen mereka. Berita yang dihasilkan dan disebarluaskan mengaktifkan struktur penghubung, untuk memfasilitasi aksi kolektif. Tindakan kolektif ini mendorong peserta berkumpul secara offline, untuk memperjuangkan tuntutan mereka. Jurnalisme warga disebut telah menjadi pendorong revolusi sosial, sebagaimana dalam kasus Arab Spring dan Mohamed Bouazizi dalam pemberontakan Tunisia 2010. Tetapi jurnalisme warga dalam hal ini dan kasus-kasus serupa biasanya fokus pada framing 'narasi martir' di mana individu dan protes atau reaksi mereka terhadap kekejaman hak asasi manusia membuat mereka sebagai simbol perjuangan untuk keadilan, martabat dan kebebasan (Pain, 2017).

Namun, dalam perjalanannya jurnalisme warga tak selalu seperti yang diharapkan. Salah satu suara kritis awal atas bangkitnya jurnalisme warga datang dari Dan Gillmor dalam bukunya We the Media. Dia bicara tentang perubahan-perubahan dalam produksi berita dan implikasinya terhadap pemahaman publik tentang berita. Khalayak kini memiliki kesempatan untuk terlibat dalam percakapan melalui teknologi interaktif dan platform digital (Gillmore, 2008). Rosenberry and St. John menyatakan, realitasnya, produksi media warga tidak berkontribusi terhadap peningkatan kehidupan publik saat ini. Gilmor dan beberapa cendekiawan lain mengatakan, perjalanan memang sangat panjang, berliku, dan terus berlanjut hingga kini (Rosenberry \& St. John, 2010).

Media sosial yang menjadi sarana jurnalisme warga merupakan salah satu bentuk media baru (new media). Penggunaan media sosial memang kian signifikan dalam dunia politik, interaksi sosial, dan pengembangan ekonomi. Hal ini ditunjukkan oleh sejumlah literatur yang menggambarkan bagaimana media sosial telah menjadi alat strategis dalam tindakan politik, promosi demokrasi, pemasaran bisnis, dan manajemen kehumasan (Brown, 2009; Coleman \& Blumler, 2009; Winograd \& Hais, 2008; Qualman, 2013).

Sejumlah riset menunjukkan fakta bahwa jaringan sosial dapat meningkatkan tingkat kesejahteraan komunitas. Misalnya, Eagle, Macy, \& Claxton (2010) mendapati bahwa struktur jaringan sosial dan keragaman hubungan individual berkorelasi dengan pengembangan ekonomi komunitas. Sementara itu, di Canberra Australia, Howard (2012) menemukan fakta yang berkesesuaian antara penggunaan media sosial oleh pemerintah lokal dengan peningkatan pelayanan publik. Riset penggunaan teknologi digital dalam tata pemerintahan (e-government) bahkan telah menjadi fenomena tersendiri dalam beberapa tahun terakhir. Di Kanada, media sosial seperti Facebook, Twitter dan Blog, juga banyak dipakai di beberapa kawasan perdesaan untuk meningkatkan kualitas kehidupan, misalnya dalam usaha pangan dan pertanian, meskipun menghadapi banyak kendala (Chowdhury \& Odame, 2013).

Harris \& Mccabe (2017) mengkaji literatur yang mengangkat tema seputar media sosial dan aksi komunitas, dalam rentang akhir 2014 sampai 2016. Tema yang mendominasi adalah kajian seputar dampak sosial penggunaan media sosial. Selain itu, tema tentang bagaimana teknologi digital ini dalam proses perubahan, pemberdayaan, dan kesetaraan, juga cukup banyak. Sementara di Indonesia sendiri, dari penelusuran melalui mesin pencari, penelitian 
seputar media sosial sebagian besar berkaitan tentang dampak media sosial terhadap masyarakat.

Ketika teknologi informasi masuk ke desa, tantangan terberatnya adalah pengetahuan (literasi), yakni bagaimana memanfaatkan teknologi tersebut untuk kehidupan seharihari. Beberapa studi menunjukkan, kurangnya pengetahuan dan penggunaan Teknologi Informasi dan Komunikasi (TIK) di daerah perdesaan mengakibatkan pembangunan berjalan pada tingkat yang sangat rendah (Tripathi, Singh, \& Kumar, 2012). Di beberapa wilayah di Jawa Tengah misalnya, penetrasi Internet terus meluas sampai ke perdesaan. Beberapa gerakan masyarakat sipil ikut mensukseskannya, antara lain melalui Gerakan Desa Membangun (GDM). Melalui GDM, para aktivis sosial mendorong dan memfasilitasi perluasan jaringan Internet ke perdesaan, selain juga mendampingi perintisan web desa (Badri, 2016). Sayangnya, GDM ini lebih berfokus ke infrastruktur dan belum masuk lebih jauh ke pemanfaatan Internet, sehingga adopsi teknologi bagi masyarakat desa juga belum maksimal. TIK akan memberikan manfaat maksimal, ketika teknologi ini memberdayakan penggunanya, baik secara individual ataupun sosial.

Beberapa upaya masyarakat sipil untuk memanfaatkan TIK bagi masyarakat desa, sehingga lebih berdaya, sebetulnya sudah berjalan, antara lain melalui jurnalisme warga di Kabupaten Brebes. Mereka memanfaatkan media sosial untuk pemberdayaan masyarakat, terutama di wilayah perdesaan. Dengan memanfaatkan Blog, Facebook, dan Twitter, mereka menjalankan praktik jurnalisme, yakni mencari, menulis, dan menyebarkan berita ke masyarakat luas. Praktik ini belum mendapatkan ruang akademis, untuk dikaji sebagai sebuah fenomena konstruksi media baru secara positif. Di sinilah tulisan ini mendapatkan relevansi, yakni sebagai upaya memperkaya kajian bidang media baru dan jurnalistik, khususnya dalam konteks pembangunan desa. Kajian ini belum banyak mendapatkan perhatian para peneliti, khususnya di Indonesia. Tulisan hasil penelitian ini bertujuan menyajikan model pemanfaatan jurnalisme warga berbasis media sosial untuk pemberdayaan masyarakat desa. Sebagai fokus kajian, dipilih praktik jurnalisme warga di Kabupaten Brebes melalui media sosial, khususnya Blog dan Facebook.

\section{METODE PENELITIAN}

Penelitian ini menggunakan desain kualitatif, dengan pendekatan pragmatik. Pendekatan ini tidak memiliki orientasi teoritik tertentu, tetapi lebih merupakan upaya menjawab sebuah persoalan konkrit dalam kehidupan manusia (Patton, 2014). Pendekatan ini menjadi relevan, khususnya untuk menghasilkan model pemanfaatan media sosial untuk pengembangan sumber daya perdesaan. Dengan metode etnografi (baik offline maupun online), penggalian data dilakukan melalui: (1) analisis isi (content analysis), (2) wawancara mendalam (indepth interview), dan (3) focus group discussion (FGD). Analisis isi dipakai untuk mengidentifikasi struktur pesan dan interaksi yang terjadi di media sosial, khususnya yang terkait dengan masyarakat atau lembaga desa. Pesan yang dimaksud adalah isi web (Blog), grup Facebook, dan Twitter yang dipakai sebagai media penyampai pesan atau informasi sebagai produk jurnalisme warga. Interaksi yang diamati meliputi komentar atau pernyataan simbolik berupa like atau retweet. Sedangkan wawancara mendalam dan FGD dilakukan untuk mendalami praktik penggunaan media sosial dalam jurnalisme warga, dengan memilih informan secara purposive, yakni warga desa yang aktif sebagai pewarta warga, para mentor, dan aparat pemerintahan desa. Peneliti menggunakan analisis naratif untuk mengeksplanasi data kualitatif. Istilah naratif menyangkut beberapa hal: sebuah hubungan di antara beberapa bagian, sebuah urutan yang membentuk semacam plot, sebuah seleksi yang menekankan mana bagian yang lebih penting dan mana yang kurang penting, dan sebuah gabungan khusus antara waktu dan tempat (Neuman, 2011). Strategi etnografi mengharuskan peneliti untuk terlibat dalam dinamika masyarakat desa dalam menggunakan media sosial.

\section{HASIL DAN PEMBAHASAN}

Penelitian ini berangkat dari masalahmasalah pembangunan di Kabupaten Brebes dan Kabupaten Pemalang. Jika mengacu pada ukuran Indeks Pembangunan Manusia (IPM), maka indikatornya adalah (1) pendidikan, (2) 
kesehatan, dan (3) ekonomi. Pertama, dari sisi pendidikan, Kabupaten Brebes menghadapi persoalan serius, yakni tingginya jumlah anak putus sekolah. Menurut data dari Dinas Pendidikan Pemuda dan Olah Raga Brebes, angka anak yang tidak sekolah mencapai sebanyak 17.645 orang. Dari jumlah itu, anak yang paling banyak putus sekolah ada di Kecamatan Bantarkawung sebanyak 1.980 anak. Lalu, Losari dengan 1.899 anak, Ketanggungan 1.359 anak, Larangan 1.289 anak dan diikuti kecamatan lain (Kumparan, 2018).

Kedua, dari sisi kesehatan, Kabupaten Brebes dihantui oleh berbagai masalah, di antaranya adalah tingginya angka gizi buruk. Pada tahun 2017, Brebes tercatat sebagai kabupaten dengan jumlah penderita gizi buruk terbanyak di Jawa Tengah. Pada bulan November 2017 lalu, Dinas Kesehatan Brebes melaporkan ada 110 pasien gizi buruk. Jumlahnya kemudian meningkat menjadi 140 orang pada Desember 2017. Penderita gizi buruk tersebar di setiap kecamatan yang ada di Kabupaten Brebes (Detik, 2018).

Ketiga, dari sisi ekonomi, Brebes pernah tercatat sebagai Kabupaten dengan jumlah orang miskin terbanyak di Jawa Tengah. Dari sensus ekonomi yang diadakan oleh BPS tahun 2015, berdasarkan angka absolut, tercatat 20 persen dari total 1,78 juta warga Brebes masuk dalam kategori miskin (Tribun Jateng, 2016).

Keberadaan para aktivis Jurnalis Warga (JW) di Brebes tak terlepas dari masalah-masalah pembangunan di kabupaten tersebut. Awalnya, mereka ini adalah inisiator grup Celoteh Brebes Membangun (CBM) di Facebook. Grup ini cukup berpengaruh di Brebes, yang nampak dari besarnya anggota yang tergabung (lebih dari 21 ribu anggota). Hampir semua pejabat Pemda Brebes tergabung dalam grup ini, baik Bupati ataupuan jajaran SKPD.

Bahrul Ulum, penggagas JW di Brebes, mengatakan, cikal bakal peran para pewarta warga ini adalah keinginan melakukan perubahan melalui penggalangan opini publik.

"Saya dulu banyak terlibat dalam program pendampingan. Saya tinggalin, (karena) sudah kurang menarik. Pengen cari sensasi yang lain. (Sekarang saya berpikir) bagaimana membangun opini publik saja. Di laptopku datanya terlalu banyak, kalau tidak saya bagi-bagi informasinya, emaneman. Statistik saya ubah menjadi bahasa media, bahasa populer. Saya pipil, menjadi tulisan." (Bahrul Ulum, wawancara pribadi, 12 September 2018).

Semangat untuk pembangunan itu, bahkan sudah nampak dari nama yang dipilih: CBM. Bahrul Ulum mengatakan:

Saya pakai nama 'celoteh', karena ini (pada dasarnya adalah) perbincangan. (dan kami) pakai nama 'membangun', karena tujuannya memang membangun. Jadi, kita ngritik dengan memberi solusi. Minimal, kita mencari sesuatu yang bisa membangun trust. Misalnya, kita menanam mangrove, dengan menggerakkan swadaya masyarakat. Kami menanam, dengan mencari donasi, utnuk area 25 hektar." (Bahrul Ulum, wawancara pribadi, 12 September 2018).

Sebagai media untuk menyampaikan berita, mereka memilih Blog, Facebook, dan Twitter. Blog dipakai sebagai platform standar media berita online (landing page), sedangkan Facebook lebih banyak dipakai untuk menyebarluaskan berita yang sudah tampil di Blog. Untuk konteks Brebes, grup FB CBM memang sangat strategis, karena anggotanya berasa dari berbagai kalangan, termasuk Bupati dan semua SKPD. Media lokalpun seringkali menyampaikan update beritanya melalui grup FB ini.

Blog yang mereka pakai menggunakan CMS (Content Management System) Wordpress, dengan nama domain (URL) www.cbmnews. net, yang kini berubah menjadi www.cbmnews. id. Perubahan ini, menurut penggagas CMB, Bahrul Ulum, karena alasan biaya. Sebelumnya, CBMNews ditangani pihak luar, lengkap dengan domain dan hosting. Untuk menghemat biaya, kini ditangani sendiri oleh komunitas CBM. Fokus isu pembangunan CBMNews nampak dalam rubrikasi yang mereka buat, seperti ekonomi, kesehatan, pendidikan, gender, kependudukan, dan demokrasi. Dari sisi updating berita, CBMNews termasuk dinamis. Dari data pemuatan artikel tahun 2018 (tabel 1), rata-rata pemuatan berita 8 kali tiap bulannya.

Dari Blog CBMNews, kemudian berkembang ke Blog yang lebih spesifik secara cakupan pemberitaan, antara lain suarapaguyangan.com, yang menjadi wadah bagi para aktivis jurnalis warga di Kecamatan 
Tabel 1 Frekuensi Pemuatan Artikel di CBMNews. id 2018

\begin{tabular}{ccc}
\hline No & Bulan & Jumlah Berita \\
\hline 1 & Januari & 11 \\
2 & Februari & 20 \\
3 & Maret & 13 \\
4 & April & 6 \\
5 & Mei & 7 \\
6 & Juni & 7 \\
7 & Juli & 10 \\
8 & Agustus & 12 \\
9 & September & 20 \\
10 & Oktober & 21 \\
\hline 11 & November & 14 \\
\hline
\end{tabular}

Sumber: Cbmnews, 2018

Paguyangan, Kabupaten Brebes. Blog untuk Paguyangan ini, menurut koordinator jurnalis warga setempat, Lidya Alfi, juga merupakan rintisan para pengelola cbmnews.id. Lidya lebih lanjut mengatakan:

Kami ini, kader-kadernya Pak Haji Ulum (Bahrul Ulum), mas Adi, Mas Lukman, Mas Herwanto. Mereka yang merintis sampai ke Paguyangan ini. Awalnya saya adalah seorang guru di Madrasah Aliyah, jurusan Bahasa Inggris. Saat itu, ada program Gerakan Kembali ke Sekolah.
Waktu itu, saya mengembalikan sembilan anak ke sekolah dari keluarga tidak mampu di Wanatirta. 7 Anak SMK, dan 2 anak SMP. Saya ketemu mas Adi. Kata Mas Adi, "Mba Lidya, ini kan bagus, mau nggak diliput?" Saya awalnya tidak tahu jurnalistik itu seperti apa, menulis itu caranya bagaimana. Saya hanya melihat dari koran untuk belajar menulis. Saya melihat Radar Tegal. Saya coba kirimkan tulisan ke mas Adi, ternyata diapresiasi. Saya akhirnya direkrut jadi JW, koordinator JW Paguyangan (Lidya Alfi, wawancara pribadi, 15 September 2018).

Adapun fitur Facebook yang mereka pakai adalah 'group'. Di grup ini, bergabung orangorang dari berbagai kalangan, mulai dari rakyat biasa, pengusaha, aktivis, hinga pejabat pembuat kebijakan. Bupati dan semua SKPD tergabung dalam grup ini. Hingga saat ini, tercatat lebih dari 21 ribu anggota. Melalui Grup FB ini, mereka bisa mendiskusikan apapun, khususnya segala hal tentang Brebes, termasuk isu-isu pembangunan.

Satu lagi, media sosial yang mereka pakai adalah Twitter. Microblogging ini lebih banyak dipakai untuk menyebarluaskan informasi tentang update CBMNews, selain untuk sekadar berbagi link berita lainnya. Twitter tidak menjadi prioritas dalam progam jurnalistik warga komunitas CBM. Ini nampak dari frekuensi update, dan jumlah follower-nya. Sampai tulisan ini dibuat, follower CBM kurang

\section{cbmnews.id}

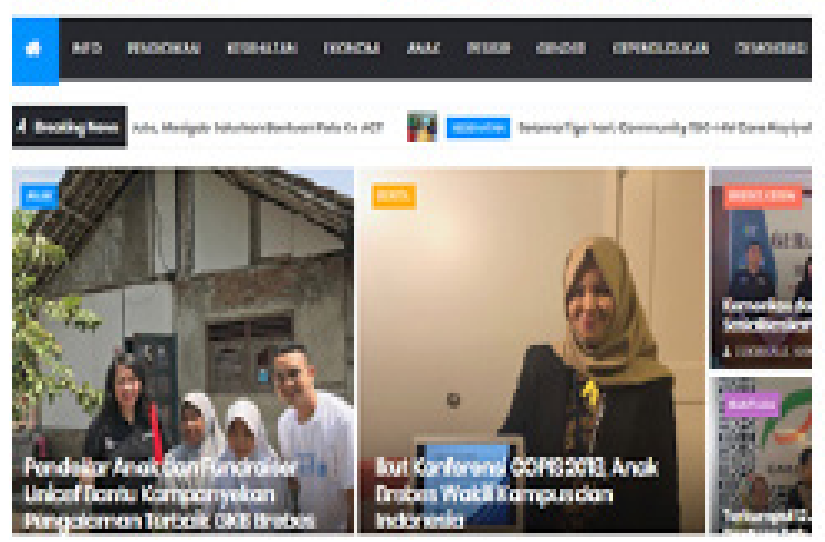

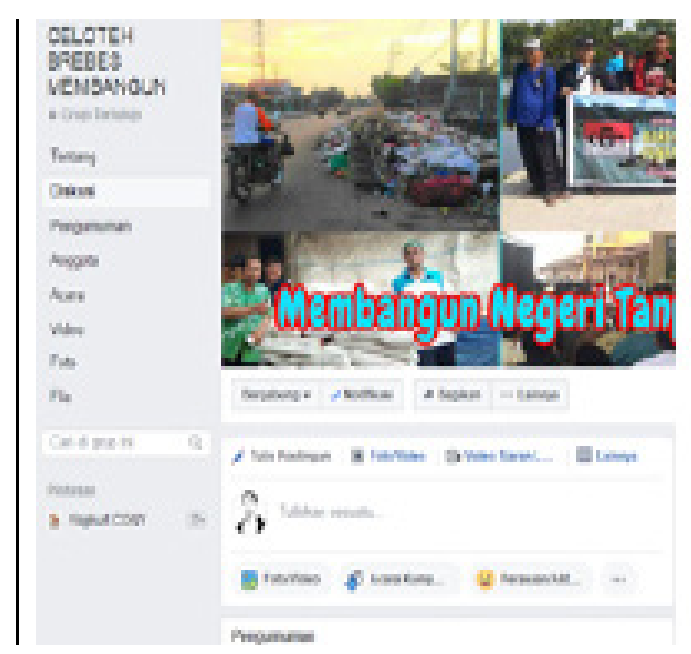

Sumber: www.cbmnews.id dan Grup FB CBM, 2018

Gambar 1 Tampilan Blog dan Grup Facebook Komunitas CBM 
dari 200.

Strategi pemanfaatan jurnalisme warga untuk mendukung program pemberdayaan masyarakat, dilakukan melalui fungsi utama jurnalime, yakni publikasi atau fungsi pengkabaran. Fungsi ini, termanifestasikan dalam beberapa fungsi khusus:

Pertama, fungsi informasi. Ini adalah fungsi jurnalisme yang paling mendasar, dimana khalayak diandaikan tidak tahu, maka menjadi kewajiban media untuk memberi tahu. Dengan prinsip $5 \mathrm{~W}+1 \mathrm{H}$, para jurnalis warga menyampaikan berbagai informasi pembangunan, mulai dari kabar seremonial (informasi kegiatan), hingga capaian-capaian prestasi. Melalui cbmnews.id, para jurnalis warga mengkabarkan berbagai peristiwa atau kejadian di desa, misalnya berita tentang kedatangan pejabat, sosialisasi kebijakan, seminar atau diskusi, kerja bakti, dan lain sebagainya. Salah seorang aktivis jurnalis warga (JW), Adi Assegaf menuturkan, sudah menjadi kewajiban seorang JW, mengkabarkan segala peristiwa yang ada di sekitar mereka, dengan tetap mengindahkan nilai-nilai jurnalistik, agar berita itu menjadi menarik. Adi Assegaf menuturkan:

Selama ini, nilai jurnalistik yang paling jadi pertimbangan adalah kedekatan. Karena warga pada dasarnya senang menyimak berita tentang daerahnya sendiri, meskipun berita itu sekadar kegiatan jalan sehat atau kerja bakti. Mereka suka desanya ditulis, atau ada foto mereka di berita itu. Dengan menulis kejadian yang dekat-dekat, juga tak menyulitkan bagi para JW. Mereka ini kan tidak dibayar, jadi tak ada biaya liputan untuk hal-hal yang jauh dari rumah mereka (Adi Assegaf, wawancara pribadi, 13 September 2018).

Kedua, fungsi advokasi. Fungsi advokasi ini diartikan sebagai pemberitaan yang berorientasi untuk pembelaan pada suatu masalah tertentu atau seseorang yang perlu dibantu. Fungsi ini biasanya dilakukan dengan pemberitaan masalah yang mendorong orang atau pembaca untuk ikut andil dalam penyelesaiannya. Misalnya, berita tentang seorang anak dari keluarga miskin yang putus sekolah. Dengan berita yang menyentuh perasaan, akhirnya jadi viral, dan mendorong banyak orang untuk membantu. Ada kisah juga tentang anak disabilitas, yang diberitakan oleh

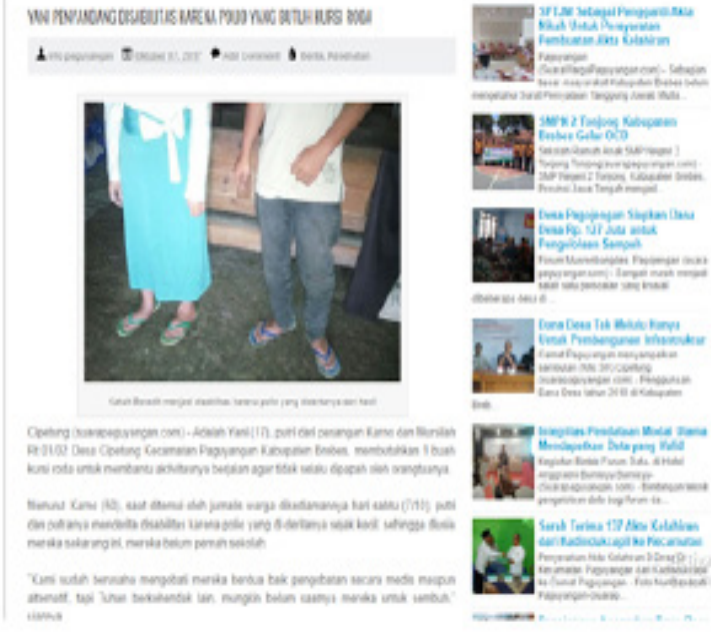

Sumber: Suarapaguyangan, 2018

\section{Gambar 2 Contoh Tulisan Advokasi Warga}

seorang jurnalis warga dari desa setempat. Anak pengidap folio yang berumur 16 tahun ini sejak kecil tak bisa berjalan. Dia berasal dari keluarga miskin, sehingga tak bisa membeli kursi roda. Pemberitaan ini akhirnya mendorong berbagai donasi. Si anak tak hanya mendapatkan kursi roda cuma-cuma, tetapi juga rumahnya yang reyot kemudian mendapat bantuan renovasi.

Fungsi advokasi ini memang akan nampak pada berita-berita yang 'kurang menyenangkan' dari masyarakat, seperti berita tentang krisis jamban atau banyaknya anak yang putus sekolah. Fungsi ini seolah mengikuti adigium klasik jurnalisme, "badnews is good news". Tapi mereka memberitakan hal buruk bukan untuk mencari sensasi, tetapi semata ingin membuka mata berbagai pihak, agar ikut membantu atau berperan serta dalam penyelesaian masalah. Bahrul Ulum menjelaskan:

Ketika kita kampanyekan penanaman mangrove, ya kita sampaikan masalahmasalah yang ada, misalnya abrasi yang makin parah. Dengan keterlibatan masyarakat, kita bisa tanam mangrove di lahan 25 hektar. Saya mobilisasi lewat medsos, (kita tawarkan donasi) per batang Rp 1000. Kita gunakan hari ulang tahun Brebes. Misalnya, 25 tahun, berarti butuh 25 ribu. Saat Proklamasi, 17 Agustus, (kita tawarkan) 17 ribu. Angka-angka unik. Pas Hari Sumpah Pemuda, (kita kampanye) "masa pemuda hanya penonton, harus jadi penuntun". Harga per batang kita tawarkan Rp 1500. Rp 1000 untuk harga per batang, 
Rp 500 untuk operasional. Kita mobilisasi, 50 orang terlibat (sebagai relawan). Sekarang, anggota DPR RI mau (terlibat). Setiap reses, mereka nyumbang untuk 1 hektar, yakni Rp 10 juta. Gak apa-apa mereka yang dari berbagai partai itu pakai nama (Bahrul Ulum, wawancara pribadi, 12 September 2018)

Ketiga, fungsi promosi. Melalui fungsi ini, jurnalis lebih banyak mengkabarkan hal-hal positif dari desa, misalnya informasi tentang pariwisata desa atau sentra usaha (UMKM). Fungsi ini sejalan dengan misi public relations desa, yakni memberitakan yang terbaik dari desa. Sehingga, prinsip pemberitaannya pun, 'good news is good news'. Fungsi ini mengandaikan, semakin banyak orang tahu hal positif tentang desa, mereka akan tertarik untuk datang ke desa. Mereka bisa datang sebagai turis yang akan membelanjakan uangnya di desa atau sebagai investor.

Menurut aktivis Jurnalis Warga Herwanto, fungsi promosi ini seperti jembatan yang menghubungkan desa dengan dunia luar. Potensi desa yang luar biasa belum terekspose ke luar, sehingga masih sulit berkembang. Herwanto mengatakan:

"Kita ini di zaman Internet yang katanya menghapuskan jarak, yang membuat tak ada lagi yang tidak terekspose. Tapi kenyataannya, masih banyak wilayah seperti perdesaan yang belum terekspose.

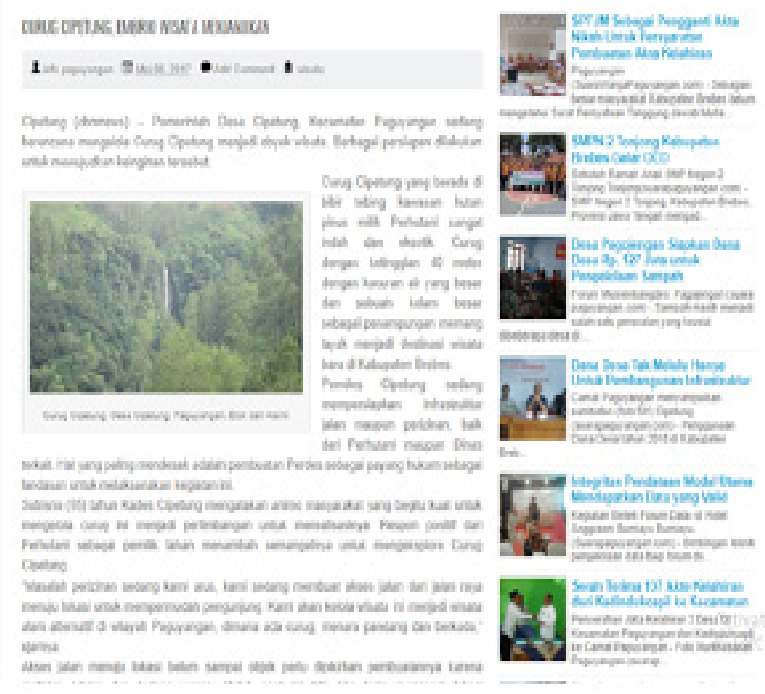

Sumber: Suarapaguyangan, 2018

Gambar 3 Contoh Berita Promosi Wisata Desa
Dan tak ada yang mau memberitakan desa, kecuali warga desa itu sendiri. Kalau di desa ada kejadian luar biasa, baru wartawan mainstream berdatangan. Kalau beritaberita positif, apalagi lingkupnya desa, mana ada yang mau nulis? Makanya, warga sendiri yang harus menuliskan desanya (Herwanto, wawancara pribadi, 2018).

Ketiga fungsi tersebut pada dasarnya merupakan upaya membentuk opini publik. Relevansinya dengan pemberdayaan, partisipasi masyarakat akan bergantung pada kesadaran. Di era Internet sekarang ini, kesadaran warga sangat dipengaruhi oleh media sosial, media yang sekarang banyak dipakai oleh warga. Kesadaran inilah yang nanti akan menggerakkan keterlibatan warga dalam berbagai program pembangunan. Jadi, sukses tidaknya berita yang dibuat oleh para jurnalis warga ini nanti nampak dari seperti apa perubahan yang bisa dihasilkan. Para aktivis JW ini pun menjadikan 'strory of change' sebagai indikator kinerja mereka. Jika digambarkan, model pemanfaatan jurnalisme warga untuk pemberdayaan masyarakat dapat dilihat pada gambar 4 .

Dengan keyakinan bahwa perubahan itu dipengaruhi oleh opini publik, maka para jurnalis warga ini berupaya secara maksimal agar berita tersebar secara luas, atau menjadi 'viral'. Mereka sadar, berita berbasis Blog tak banyak yang tiba-tiba mengakses, maka perlu strategi khusus agar berita di Blog tersebut diketahui. Salah satu strateginya adalah menginformasikan setiap update berita di grup Facebook. Faktanya, memang orang lebih banyak mengakses Facebook ketimbang Blog. Apalagi grup Facebook CBM sangat strategis, baik dari sisi banyaknya anggota maupun variasi dan kualifikasi anggotanya. Saat ini, tercatat lebih dari 20 anggota grup ini. Di Grup ini, Bupati, SKPD, dan anggota DPRD Kabupaten Brebes ikut bergabung. Jadi, berita-berita seputar pembangunan bisa langsung direspons oleh instansi terkait.

Popularitas Grup Facebook tersebut kemudian juga dimanfaatkan untuk publikasi kegiatan berbagai pihak, termasuk untuk publikasi pemberitaan oleh media mainstream. Beberapa media lokal seperti Suara Merdeka atau Radar Tegal sering kali menautkan link update berita mereka, terutama untuk berita-berita yang menyangkut masyarakat di 


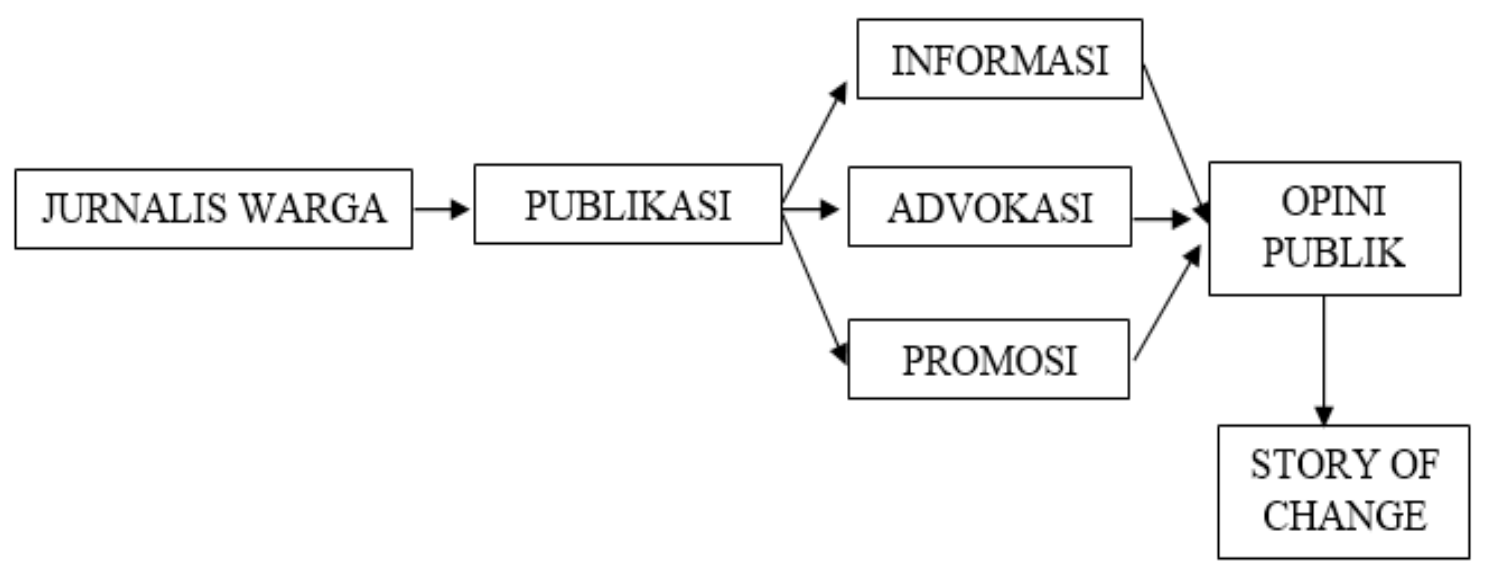

Sumber: Hasil Penelitian, 2018

Gambar 4 Model Pemanfaatan Jurnalisme Warga

Kabupaten Brebes.

Hubungan antara media mainstream ini dan jurnalis warga kemudian menjadi saling membutuhkan. Masing-masing memiliki kelebihan yang bisa disinergikan. Media mainstream memiliki integritas dan gengsi, sedangkan media warga memiliki daya jangkau lokalitas. Maksudnya, para jurnalis warga yang tersebar di beberapa desa ini memiliki keunggulan kecepatan untuk memberitakan peristiwa di desanya masing-masing. Misalnya, Mardiana dari Desa Kedungoleng, Kacamatan Paguyangan, yang beritanya sering dikutip Harian Radar Tegal. Mardiana mengatakan:

"Kebetulan rumah saya dekat dengan dengan jalan layang yang belum lama dibangun. Sering terjadi kecelakaan di situ. Saya menulisnya segera, kalau ada kecelakaan. Tak tahunya, di Radar Tegal juga muncul berita yang saya tulis. Mereka tak menghubungi saya, untuk minta ijin. Karena sudah ada kesepakatan sebelumnya, mereka boleh mengutip berita dari Suara Paguyangan. Gak apa-apa sih, saya malah seneng, tulisannya tersebar sampai ke koran (Mardiana, wawancara pribadi, 15 September 2018).

Pada akhirnya, peran jurnalisme warga ini akan terkait dengan jangkauan pemberitaan mereka. Untuk tujuan ini, dari Kabupaten Brebes, para aktivis jurnalis warga ini terus memperluas jaringan, sampai ke Kabupaten
Pekalongan dan Pemalang. Di Kabupaten Pekalongan, jurnalis warga di Kecamatan Petungkriyono sempat mengelola Blog www. petungkriyono.com (sekarang sudah tidak aktif). Sedangkan di Kabupaten Pemalang, para jurnalis warga setempat mengelola Blog www.suarawargabelik.xyz. Para aktivis ini juga berjejaring dengan bergabung dalam Perhimpunan Pengembangan Media Nusantara (PPMN).

Kontribusi jurnalisme warga ini dirasakan manfaatnya, baik secara individual maupun sosial. Secara individual, para jurnalis warga merasa bertumbuh, baik dari sisi mental (rasa percaya diri) ataupun kapasitas pengetahuan. Inilah hakikat berdaya secara personal. Seperti sosok Purni, warga Petungkriyono, sebagaimana dikisahkan mentornya, Lukman, aktivis jurnalis warga Brebes. Purni tinggal di Desa Kayupuring Kecamatan Petungkriyono Kabupaten Pekalongan. Desa ini berjarak sekitar 30 KM dari Ibukota Kabupaten. Mayoritas penduduknya miskin, yang bekerja sebagai buruh tani. Purni sendiri adalah seorang ibu rumah tangga, yang bekerja paruh waktu sebagai surveyor di Puskesmas. Awalnya, cerita Purni, peran perempuan sangat terpinggirkan. Program-program pembangunan desa nyaris tak pernah melibatkan perempuan.

Sejak 2017, Purni bergabung dengan komunitas jurnalis warga yang diinisiasi para aktivis dari Kabupaten Brebes. Selain Purni, ada empat orang lainnya, jurnalis warga dari 
Desa Kayupiring. Status sebagai jurnalis warga membuat Purni lebih percaya diri. Dia mulai terlibat dalam forum 'Selapanan' dengan meliput agenda kegiatannya. Forum ini cukup strategis, karena para anggotanya terlibat dalam musyawarah dusun (Musdus). Untuk pertama kalinya, Purni diundang dalam rapat pemerintahan desa, setelah dia aktif sebagai jurnalis warga.

Purni merasa kian berarti bagi masyarakat sekitarnya. Satu tulisannya tentang disabilitas viral, mendapatakan respons dari berbagai pihak, termasuk dari pemerintah setempat. Purni pun kini bisa menyuarakan gagasannya dalam penyusunan RAPBDes. Beberapa program kemudian lahir, antara lain Forum Masyarakat Sipil (Formasi) mengorganisasikan pendidikan perempuan miskin dan disabilitas dalam kelompok 'selapanan', serta meningkatkan pengetahuan dan kapasitas mereka untuk berinteraksi dengan pemerintah.

Bagi masyarakat, peran para jurnalis warga ini juga signifikan. Dalam aksi lingkungan berupa penanaman mangrove misalnya, telah membawa keuntungan sosial maupun ekonomi. Masyarakat pesisir Brebes selama ini merasakan betapa dampak kerusakan lingkungan memiliki serius. Kabupaten Brebes memiliki 56,68 $\mathrm{Km}$ garis pantai, dengan Delta Pemali di sisi timur dan Delta Cisanggarung di sisi barat. Kedua delta tersebut berbentuk cuspate atau $\mathrm{V}$ membulat, dengan beberapa cabang sungai yang mengalirkan material lumpur hulu dan tengah DAS ke wilayah kepesisiran Brebes (Faperi, et al. 2015). Proses alam kemudian membentuk daratan baru yang sering disebut sebagai tanah timbul. Tanah timbul ini dimanfaatkan oleh masyarakat sebagai lahan tambak udang sejak tahun 1980an ketika udang windu menjadi primadona. Keuntungan yang menggiurkan kemudian mendorong warga setempat membudidayakan udang windu secara masif. Tanah timbul itu oleh warga dibuat kolam-kolam tambak. Perubahan morfologi tanah akibat pembuatan tambak ini menyebabkan masalah, karena menjadikan ketahanan terhadap arus air laut berkurang. Laju erosi kemudian meningkat. Pengikisan tanah ini lambat laun membuat tambak rusak, sehingga terjadi paceklik. Tambak-tambak yang pernah berjaya itu kemudian hilang. Perekonomian warga menurun drastis, sehingga memengaruhi kehidupan sosialnya. Sejak tahun 2000-an, banyak warga setempat yang merantau, mencari sumber penghasilan baru. Tak sedikit dari mereka yang kemudian menjadi buruh kasar seperti anak buah kapal atau pembantu rumah tangga. Kondisi inilah yang perlahan berubah oleh aksi lingkungan yang dikampanyekan melalui jurnalisme warga. Dengan menanam mangrove, selain berfungsi menahan laju abrasi, juga memperluas habitat berbagai hewan laut, seperti ikan dan kepiting. Habitat yang terjaga pada akhirnya, warga setempat juga yang merasakan manfaatnya. Belum lagi potensi ekowisata dari hutan mangrove, ke depan akan menjadi pemasukan tambahan untuk masyarakat dan pemerintah daerah.

Di bidang pendidikan, para aktivis JW juga berhasil ikut mengentaskan anak-anak yang putus sekolah. Seperti yang diakui Lidya Alfi, JW dari Paguyangan, dia merasa bangga telah berhasil mengembalikan sembilan anak yang putus sekolah.

"Bangga rasanya kami bisa mengembalikan sembilan anak yang putus sekolah. Jadi, awalnya cari data, siapa saja yang putus sekolah. Kita cari akar masalahnya, terus kita coba bantu membuat solusi. Jika masalanya biaya, kami galang donasi dari berbagai pihak" (Lidya Alfi, wawancara pribadi, 15 September 2018).

Menurut perintis jurnalis warga di Brebes Bahrul Ulum, program pengentasan anak tidak sekolah (ATS) ini dirintis sejak tahun 2013.

"Anak Tidak Sekolah ini, ada beberapa kriteria, yang akan kita entaskan, yaitu: disabilitas, tak bisa mengenyam pendidikan, putus sekolah, dan anak tidak lanjut ke jenjang berikutnya. Di Brebes ini, jumlahnya mencapai 27 ribu anak. Waktu itu meyakinkan Bupati dan DPR juga tidak mudah. Saya katakan jumlah itu riil, dengan asumsi (terdapat) 50 anak putus sekolah per desa" (Bahrul Ulum, wawancara pribadi, 12 September 2015).

Kontribusi sosial jurnalisme warga ini pada umumnya dilakukan melalui penggalangan dana dari masyarakat melalui kampanye media (crowd funding). Semua diawali oleh program yang mereka canangkan. Misalnya dalam bidang kesehatan, mereka membuat program pembuatan jamban murah, mengingat di beberapa wilayah masih banyak warga yang 
belum memiliki jamban. Mereka kemudian menawarkan bentuk kontribusi masyarakat, misalnya Rp 1 juta untuk satu jamban per rumah. Agar masyarakat juga terberdayakan dana tersebut tidak diberikan semuanya, tapi hanya separuh dan mereka harus menggenapi sisanya. Dengan begitu, dana yang tersisa bisa dipakai untuk warga yang lain, sehingga jangkauan program bisa lebih meluas.

Mereka menggunakan kekuatan narasi untuk mendorong keterlibatan masyarakat setempat, seperti dikatakan Bahrul Ulum:

Misalnya, kita sampaikan, siapa yang mau investasi akhirat? Silahkan sisihkan Rp 1,5 juta untuk mengentaskan anak SMP yang putus sekolah atau untuk SD Rp 1,3 juta. Setelah ada yang mau, ini seperti pancingan, yang lain ikut. Kita buat fleksibel cara partisipasinya, misalnya ada yang nyicil, 2-3 kali, tidak masalah. Yang tertarik kemudian ada 30 orang. Ini untuk inisiasi. Kita publish terus, sampai pemerintah memberikan perhatian pada masalah ATS ini. Masa pemerintah ga mau turun? Kita sudah ikut naikkan IPM lho (Bahrul Ulum, wawancara pribadi, 12 September 2018).

\section{Strategi jurnalistik yang menekankan nilai human interest menjadi strategi} tersendiri. Seperti kisah-kisah Wisnu yang mereka blow-up, untuk menunjukkan betapa menyedihkannya mereka yang putus sekolah. Seorang jurnalis warga di Kamal bertemu Wisnu, seorang anak yang putus sekolah. Setiap hari Wisnu berjualan sate tepung. Orang selalu iba melihatnya, dengan baju ala kadarnya, dengan sepeda yang bannya diikat karet, karena tak bisa beli ban baru. Diceritakan, Wisnu yang punya seorang adik usia TK ini tinggal bersama neneknya. Bapaknya menikah lagi, begitu juga ibunya. Cerita tentang Wisnu ini menjadi viral, terutama sejak media mainstream ikut juga memberitakan. Bahrul Ulum menjelaskan:

Kisah Wisnu ini akhirnya menjadi pendobrak warga di sana. Kita blow up besar-besaran, kemudian dapat sumbangan sekitar Rp 12 juta. Dramanya kita tonjolkan memang. JW datang ke rumahnya, kita foto, termasuk jalan menuju kampungya yang memprihatinkan. Jadi menyentuh buat yang baca. Kita bahkan buat film Wisnu, jadi film pergerakan kita. Versi anak soleh, karena ga ada duitnya, hehe. Wisnu, kita kembangkan jadi GKB, Gerakan Kembali Bersekolah. Setelah itu, di tengah perjalanan ketemu Surya. Penggembala sapi, kelas 3, putus sekolah juga. Kita ketemu tahun berikutnya. Bapaknya sudah meninggal, sebulan berikutnya ibunya meninggal. Kita cari bapak asuh, dan ada yang merespons (Bahrul Ulum, wawancara pribadi, 12 September 2018).

Di sini, bisa ditandaskan, strategi jurnalistik dengan mengandalkan kekuatan narasi yang berpadu dengan aktivisme sosial telah menjadi energi positif dan konstruktif dalam program pembangunan masyarakat. Ada masalah dalam masyarakat di satu sisi dan ada pihak-pihak yang bisa berkontribusi di sisi lainnya, dan kemudian jurnalisme yang mempertemukan dua sisi tersebut.

Pemanfaatan media sosial melalui praktik jurnalisme warga ini bisa menjadi bagian dari program internasional, yakni "Information and Communication Technology for Development" (ICT4D). Program semacam bisa menjadi inisiasi pemerintah atau masyarakat sipil yang mendorong pemanfaatan teknologi informasi dan komunikasi (TIK) untuk pengembangan masyarakat, seperti program 'One Laptop per Child'(Toyama, 2011).

\section{SIMPULAN}

Kontribusi jurnalis warga di Kabupaten Brebes dalam program pemberdayaan masyarakat berfokus pada tiga isu utama, yakni pendidikan, kesehatan, dan lingkungan. Dari ketiga hal itu diharapkan berkontribusi pada aspek ekonomi. Praktik jurnalisme warga di Kabupaten Brebes menggunakan media sosial sebagai sarananya, khususnya Blog, Facebook, dan Twitter. Strategi pemberdayaan masyarakat melalui jurnalisme warga dilakukan dengan penggalangan opini publik, dalam upaya membangun kesadaran dan partisipasi masyarakat. Penggalangan opini publik itu dilakukan dengan menekankan pada fungsi informasi, fungsi advokasi, dan fungsi promosi. Fungsi informasi semata mengkabarkan peristiwa atau kejadian, dengan menekankan unsur berita $(5 \mathrm{~W}+1 \mathrm{H})$. Fungsi advokasi berpretensi melakukan gerakan, yang berangkat dari kasus tertentu. Sedangkan fungsi promosi berupaya menampilkan potensi-potensi 
wilayah, baik ekonomi maupun wisata ke pihak luar.

Indikator kinerja para jurnalis warga dilihat dari dampak tulisan. Mereka membuat istilah 'story of change'. Maksudnya, seberapa besar tulisan membawa perubahan. Semakin banyak perubahan yang diakibatkan, semakin sukses sebuah tulisan. Dampak perubahan akan dipengaruhi oleh seberapa luas tulisan menyebar. Maka, para jurnalis warga berupaya agar tulisannya menyebar secara luas. Mereka tak hanya menggunakan berbagai platform media sosial untuk mempopulerkan tulisan, tetapi juga bekerja sama dengan media mainstream. Banyak tulisan jurnalis warga yang dimuat di media mainstream. Untuk menata kerja para jurnalis warga dan memperluas jangkaun peran, mereka terus mengkader jurnalis warga di tempat lain, sehingga dari Kabupaten Brebes, praktik jurnalisme warga ini berkembang ke Kabupaten Pekalongan dan Pemalang. Jurnalisme warga memberdayakan atau memberikan manfaat secara individual bagi para jurnalisnya maupun secara sosial bagi masyarakat. Secara individual, mereka merasa bertumbuh, baik secara mental atupun kapasitas pengetahuan. Secara sosial, banyak hal yang sudah bisa dirasakan masyarakat sekitar. Sejauh ini, program utama para jurnalis warga dalam mendorong masyarakat untuk agenda-agenda sosial maupun pembangunan dilakukan dengan penggalangan dana dari berbagai pihak, baik swasta maupun pemerintah (crowd funding). Strategi crowd funding antara lain dilakukan dengan membuat narasi jurnalistik yang menyentuh emosi, dengan menekankan nilai human interest dalam tulisan berita. Semakin menyentuh sebuah tulisan, semakin banyak yang baca, akan semakin tinggi peluang orang untuk ikut berpartisipasi.

\section{DAFTAR PUSTAKA}

Asosiasi Penyelenggara Jasa Internet Indonesia. (2017). Survei internet apjii 2016. Retrieved december 16, 2018, from https:// apjii.or.id/content/read/39/264/SurveiInternet-APJII-2016.

Badri, M. (2016). Informasi dan komunikasi (studi pada gerakan desa membangun). Jurnal Risalah, 27(2), 62-73.

Brebes peringkat pertama jumlah penduduk miskin di Jateng - Tribun Jateng. (2016).
Retrieved December 18, 2018, from http:// jateng.tribunnews.com/2016/02/24/brebesperingkat-pertama-jumlah-pendudukmiskin-di-jateng.

Brown, R. (2009). Public relations and the social web: how to use social media and Web 2.0 in communications. Kogan Page.

Chowdhury, A. \& Odame, H. H. (2013). Social media for enhancing innovation in agri-food and rural development: current dynamics in ontario, Canada, 8(2), 97-119.

Coleman, S. \& Blumler, J. G. (2009). The internet and democratic citizenship: theory, practice and policy. Cambridge University Press.

Detik. (2018). Jumlah penderita gizi buruk tertinggi di Jawa Tengah ada di Brebes. Retrieved December 18, 2018, from https://news.detik.com/berita-jawatengah/d-3853074/jumlah-penderita-giziburuk-tertinggi-di-jawa-tengah-ada-dibrebes.

Eagle, N., Macy, M., \& Claxton, R. (2010). Network diversity and economic development. Science (New York, N.Y.), 328(5981), 1029-1031. https://doi. org/10.1126/science.1186605.

Gillmore, D. (2008). We the media:grassroots journalism by the people, for the people (first edit). Sebastopol CA: O'Reilly Media.

Gündüz, U. (2017). The effect of social media on identity construction. Mediterranean Journal of Social Sciences, 8(5), 85-92. https://doi.org/10.1515/mjss-2017-0026.

Harris, K. \& Mccabe, A. (2017). Community action and social media: a review of the literature. Retrieved from https://www. birmingham.ac.uk/generic/tsrc/documents/ tsrc/working-papers/Working-Paper-139Community-Action-and-Social-MediaFinal-2.pdf.

Hartoyo, N. M. \& Supriadi, D. (2015). Aktivisme sosial melalui penggunaan media sosial: studi kasus Asosiasi Ibu Menyusui Indonesia (AIMI). Jurnal Kajian Komunikasi, 3(1), 1-11. https://doi. org/10.24198/jkk.v3i1.7388.

Kompas (2017). Jokowi: stop penyebaran berita bohong, fitnah, dan kebencian di medsos. Retrieved December 16, 2018, from https://nasional.kompas.com/ $\operatorname{read} / 2017 / 06 / 08 / 18261731 /$ jokowi.stop. 
penyebaran.berita.bohong.fitnah.dan. kebencian.di.medsos.

Kompas. (2017). Komisioner KPK sebut dana desa banyak diselewengkan. Retrieved December 17, 2018, from https://nasional. kompas.com/read/2017/05/18/15414991/ komisioner.kpk.sebut.dana.desa.banyak. diselewengkan.

Mody, B. (2011). Student civic engagement with humanitarian disasters: collaborative cross-national research on Darfur reporting. Journal of African media Studies. 3(3), 349-366. https://doi.org/10.1386/ jams.3.3.349_1.

Mujahiddin, M.\& Harahap, M. S. (2017). Model penggunaan media sosial di kalangan pemuda. Jurnal Interaksi, 1(2), 142-155. https://doi.org/10.30596/JI.V1I2.1200.

Mulawarman \& Nurfitri, A. D. (2017). Perilaku pengguna media sosial beserta implikasinya ditinjau dari perspektif psikologi sosial terapan. Buletin Psikologi. 25(1), 36-44. https://doi.org/10.22146/ buletinpsikologi.22759.

Nah, S., Namkoong, K., Record, R., \& Van Stee, S. K. (2017). Citizen journalism practice increases civic participation. Newspaper Research Journal, 38(1), 62-78. https:// doi.org/10.1177/0739532917698444.

Neuman, W. L. William L. (2011). Social research methods: qualitative and quantitative approaches (7th ed.). Boston: Allyn \& Bacon.

Ningtyas, I. (2014). Demokratisasi media melalui jurnalisme warga. Retrieved December 13, 2018, from http://www. remotivi.or.id/amatan/33/DemokratisasiMedia-Melalui-Jurnalisme-Warga.

Pain, P. (2017). Educate empower . revolt educate . empower . revolt Framing citizen journalism as a creator of social movements. Journalism Practice, 12(7), 1-18. https://doi.org/10.1080/17512786.2 017.1343094.

Patton, M. Q. (2014). Qualitative research \&amp; evaluation methods: integrating theory and practice. London: Sage.

Qualman, E. (2013). Socialnomics: how social media transforms the way we live and do business. New Jersey: John Wiley.

Ribuan anak di Brebes alami putus sekolah kumparan.com. (2018). Retrieved
December 18, 2018, from https://kumparan. com/panturapost/ribuan-anak-di-brebesalami-putus-sekolah.

Rosenberry, J. \& St. John, B. (2010). Public journalism 2.0 : the promise and reality of a citizen-engaged press. Routledge.

Solekhan \& Winarso, R. (2016). Pemanfaatan media sosial sebagai media pemasaran sangkar burung di Kabupaten Kudus. Prosiding SNATIF. (pp. 445-448). Retrieve from https://jurnal.umk.ac.id/index.php/ SNA/article/view/683/695.

Stark, M., Fins, J. J., \& Stark, M. (2012). The self, social media, and social construction the self, social media, and social construction. The American Journal of Bioethics, 12(10), 37-39. https://doi.org/10.1080/15265161.2 012.708094 .

Toyama, K. (2011). Technology as amplifier in international development (pp. 75-82). Seatle, Washington, USA.

Tripathi, A. M., Singh, A. K., \& Kumar, A. (2012). Information and communication technology for rural development, International Journal on Computer Science and Engineering (IJCSE). 4(05), 824-828. Retrieve from http://www.enggjournals. com/ijcse/doc/IJCSE12-04-05-131.pdf.

Vebrynda, R., Maryani, E., \& Abdullah, A. (2017). Konvergensi dalam program net citizen. Jurnal Kajian Komunikasi, 5(1), 53-68. https://doi.org/10.24198/jkk. v5i1.7432.

Wedhaswary, I. D. (2009). Perkembangan jurnalisme warga di Indonesia: Studi kasus padaMetroTV,RadioElshinta, www.kompas. com, www.panyingkut.come. Universitas Gadjah Mada. Retrieved from https:// repository.ugm.ac.id/80203\%0Ahttp:// e $\mathrm{t} d$. u g m . a c . i d / i n d e x. elitianDetail\&act $=$ view\&typ $=$ html\&buku $\mathrm{id}=41067$.

Winograd, M. \& Hais, M. D. (2008). Millennial makeover: myspace, youtube, and the future of american politics. Rutgers University Press. Retrieved from https://books.google. co.id/books/about/Millennial_Makeover. html?id=es5Fo0LNk24C\&redir esc $=y$.

Yousefikhah, S. (2017). Sociology of innovation: Social construction of technology perspective. AD-Minister, 30(1), 31-43. https://doi.org/10.17230/ad-minister.30.2. 